Rev. Interd. em Cult. e Soc. (RICS), São Luís, v. 6, n. 2, p. 248-264, jul./dez. 2020

ISSN eletrônico: $2447-6498$

\title{
O Emaranhado de Fios dos Relatos de Infância: o Gênero Autobiográfico em Recuerdos de Niñez y Mocedad de Miguel de Unamuno
}

\author{
The threads' tangle of childhood relationships: the autobiographical \\ gender in Recuerdos de niñez y mocedad by Miguel de Unamuno
}

\author{
WALTER PINTO DE OLIVEIRA NETO \\ Bolsista PIBIC do Curso de Letras Português/Espanhol da UEMA \\ walteroliveira16@outlook.com
}

\author{
ANDREA TERESA MARTINS LOBATO \\ Doutora em Letras. Professora Adjunta II da UEMA \\ andreatmlobato@gmail.com
}

\section{RESUMO}

Recuerdos de niñez y mocedad (1908) é uma obra autobiográfica do escritor Miguel de Unamuno (1864 - 1936), na qual o autor narra diversas experiências da infância e adolescência. Nela, Unamuno aborda algumas lembranças que, por se manterem longe na distância e no tempo, confundem-se em fios emaranhados entre o real e o fictício. Para analisar o relato de infância do modernista espanhol, valemo-nos de estudiosos do gênero autobiográfico e psicanalistas como Braunstein (2008). Assim sendo, o estudo buscou analisar e encontrar traços do gênero autobiográfico na obra do intelectual, da mesma maneira que os recursos linguísticos para encobrir as camadas nebulosas da memória. Tendo por base estes preceitos, a partir da metodologia bibliográfica de cunho qualitativo, explicaremos como as recordações de Don Miguel, em Recuerdos de niñez y mocedad, são descritas vários anos após a infância ter se tornado, somente, "pontos que estão contidos em enormes espaços vazios".

Palavras-chave: Autobiografia. Infância. Unamuno.

\begin{abstract}
Recuerdos de niñez y mocedad (1908) is an autobiographical work by the writer Miguel de Unamuno (1864 1936), in which the author describes various experiences of childhood and adolescence. In it, Unamuno addresses some memories that, being far away in time and distance, get confused in tangled threads between the real and the fictional. To analyze the childhood report of the Spanish modernist, we will use autobiographical scholars and psychoanalysts such as Braunstein (2008). Therefore, the study sought to analyze and find traces of the autobiographical genre in the intellectual's work, as well as the linguistic resources to cover the foggy layers of memory. Based on these precepts, from the qualitative bibliographical methodology, we will explain how the memories of Don Miguel, in Recuerdos de niñez y mocedad, are described several years after childhood only became "points that are contained in huge empty spaces".
\end{abstract}

Keywords: Autobiography; Childhood; Unamuno.

\section{INTRODUÇÃO}

Em uma pequena vila do interior de Bilbao nasce a meados do séc. XIX uma criança que algumas décadas mais tarde se converteria em um dos grandes escritores e pensadores modernos da Espanha. Não obstante, antes de se tornar a figura mais representativa da Geração de 98, Miguel de Unamuno vive uma infância cheia de tentames que o influenciaram no quesito existencial, artístico e temático das futuras produções literárias. 
Rev. Interd. em Cult. e Soc. (RICS), São Luís, v. 6, n. 2, p. 248-264, jul./dez. 2020 ISSN eletrônico: 2447-6498

No tranquilo bairro periférico de Siete Calles, os pais de Don Miguel, Félix María de Unamuno e María de Salomé Unamuno, olhavam intrépidos as cada vez mais frequentes aparições de grandes e poderosas máquinas vindouras de todos os cantos da nação. O progresso e a modernidade já haviam chegado aos pueblos $^{1}$ mais afastados da capital da comunidade autônoma do País Basco.

Entretanto, os bilbaenses ${ }^{2}$ não sentiam muita curiosidade pelos avanços tecnológicos, dado que a região, localizada ao norte da Espanha, historicamente sempre se manteve arraigada num tradicionalismo que é manifestado por uma cultura e língua própria. Dessa forma, Félix e sua esposa 17 anos mais jovem, preocupavam-se mais com a manutenção de um pequeno negócio familiar, e, principalmente, com a sustentação de filhos que iam eclodindo a ritmos vertiginosos. O segundo dos filhos do casal, e o primeiro varão, recebe o nome de Miguel, o qual, em 1864, em "lo más lúgubre y sombrío de Bilbao, en una calle, amasada en humedad y sombras, donde la luz no entra, sino derritiéndose" (UNAMUNO apud RABATÉ; RABATÉ, 2010, p. 20), é visto pela sua progenitora por primeira vez.

A infância e adolescência de Miguel de Unamuno são marcadas pela doutrinação religiosa, o interesse pela arte, a convivência com eventos bélicos e um forte vínculo com a paisagem montanhosa do pueblo bilbaino. Estes e outros componentes instigariam ao escritor durante toda sua existência, chegando a reconhecer que, nos momentos mais difíceis da vida adulta, precisaria acudir a essas recordações para refrescar-se com o manancial das lembranças da infância:

Se oyen en el silencio los ecos dulces de la niñez lejana como rumor de aguas vivas y frescas de humilde arroyo que seguían fluyendo bajo las secas y ardientes arenas. $Y$ entonces, secas las fauces y resquebrajadas las entrañas espirituales, sedienta el alma hasta la agonía se escarba con afán el suelo hasta descarnarse las manos, para descubrir aquellas aguas rumorosas y caer postrado de bruces y beberlas y recobrar vida con el manantial que, corriendo en oscuro subterráneo, preservo su pureza y su frescura. (UNAMUNO, 2005, p. 144).

Assim sendo, ao entrar na etapa madura, Don Miguel começa a escrever muitos e variados textos em que as experiências quando garoto de uma comunidade rural, evidenciar-seiam com um toque poético e nostálgico; ao mesmo tempo em que o eu que se torna adulto, perde a característica mais preciosa e perene do ser humano: ser criança. Escrever, portanto,

\footnotetext{
${ }^{1}$ Pequenas cidades situadas nos interiores da Espanha. España profunda como alguns espanhóis denominam até hoje.

${ }^{2}$ Gentilício de quem é da cidade Bilbao.
} 
Rev. Interd. em Cult. e Soc. (RICS), São Luís, v. 6, n. 2, p. 248-264, jul./dez. 2020

ISSN eletrônico: 2447-6498

serve como remédio, como phármakon (conceito de Derridá que retomaremos mais adiante), diante de uma existência incompleta que perpetuamente tenta reencontrar um pouco da felicidade, otimismo e despreocupação distintiva da criança. Nesse sentido que a arte, a escrita, a literatura, faz sentido, pois:

A arte funciona para o artista como fonte de vida, sem a qual a existência não teria nenhum sentido. Verifica-se, assim, que (...) a obra literária vem responder a uma tensão violenta e contribui para o esvaziamento desta tensão. O que não era possível antes - viver - torna-se possível depois para o escritor, desde que o mesmo esteja sempre amparado ao que o sustenta: a arte. (LINS, 1980, p.9).

Contudo, a psicanálise abriu a vereda para um novo modelo de interpretação dessas lembranças tão distantes no tempo. Braunstein (2009), afirma que "el recuerdo de infancia ha perdido en encantos y ha ganado en oscuridad después de haberse reconocido la validez universal de los "recuerdos encubridores"” (p. 200). A memória, ao ter que se deslocar tantos anos, apresenta-se como uma base movediça e, portanto, isenta de solidez. Por esta razão que estudar os relatos de infância por meio, exclusivamente, da teoria literária, parece-nos que atinge só a superfície de um vasto e inexplorado mundo introduzido nas camadas mais interiores da mente. Sendo assim, além de teóricos que tratam sobre o gênero autobiográfico, explicitamente o subgênero dos relatos de infância, faremos uso da teoria psicanalítica, servindo-nos de Braunstein (2009) e Freud (1981), principalmente, para fundamentar nossa análise. Tendo por base estes preceitos, explicaremos como as recordações do autor espanhol, em Recuerdos de niñez y mocedad (1908), são descritas vários anos após a infância ter se tornado, somente, "pontos que estão contidos em enormes espaços vazios." (WOOLF, 1986, p. 91).

\section{RECUERDOS DE NIÑEZ Y MOCEDAD, UMA OBRA SUPOSTAMENTE IRRELEVANTE}

Os autores da Geração de $98^{3}$ se caracterizaram por terem escrito uma grande quantidade de textos, limitando-se não somente à ficção, mas a todos os gêneros possíveis da literatura. Isto se deveu ao alto grado de participação social e política, no séc. XIX e XX, em

\footnotetext{
${ }^{3}$ Grupo de intelectuais espanhóis do final do séc. XIX e início do séc XX, que "hablarán del sentimiento trágico de la vida en el hombre y en los pueblos; de la esencia y el significado de lo español en relación a lo europeo (...), una serie de cuestiones aparecen como, más o menos, comunes a todos ellos: el paisaje y el problema de la cultura hispana, la cuestión de la decadencia de España y, concretamente, de Castilla (...) tratados de formas muy distintas (...) pero que presentan unos rasgos generaciones de reflexión, opinión y actitud compartidos" (JUTGLAR, 1973, p. 110-111).
} 
Rev. Interd. em Cult. e Soc. (RICS), São Luís, v. 6, n. 2, p. 248-264, jul./dez. 2020 ISSN eletrônico: 2447-6498

que a Espanha se encontrava no meio de uma das grandes crises da sua história ${ }^{4}$. Unamuno, considerado por muitos críticos a figura mais destacada dentre os intelectuais dessa geração de eruditos, é o que deixou o mais extenso legado literário. O conjunto da obra remete a um extenso e profundo acervo que

Conta com seiscentos trinta e um ensaios publicados, oitocentos artigos em jornais e revistas da Espanha e América Latina, cinco romances, oito novelas e cento cinquenta e dois contos, oito livros de poemas e mais cento e onze poemas dispersos em publicações, e mil setecentos e cinquenta e cinco poemas inéditos. Escreveu cinquenta e quatro prólogos, proferiu mais de cem conferências, e entre suas correspondências contam mais de mil cartas, ademais de obras teatrais. (OLIVEIRA, 2016, p. 13).

Algumas obras como Niebla (1907) ou Del Sentimiento Trágico de la Vida (1912), foram traduzidas ao redor do planeta, colocando ao autor bilbaíno como um dos escritores espanhóis mais lidos do século XX até os dias atuais. Não obstante, outras obras não receberam o aval da crítica, resultando em um baixo número de vendas. Recuerdos de Niñez y Mocedad, obra pertencente à segunda fase ${ }^{5}$ da produção unamuniana, resultou num fracasso a nível editorial sem precedentes. Ainda assim, parece-nos interessante que, apesar do pouco número de vendas da obra, Unamuno tenha dito que "trece volúmenes llevo ya publicados, pero de todos ellos no pienso volver a leer sino uno, el de mis Recuerdos de niñez y mocedad, donde en días de serenidad ya algo lejana, traté de fijar no mi alma de niño, sino el alma de la niñez" (UNAMUNO, 2005, p. 352 - 353). Contudo, apesar de comentar que, na obra, fale-se sobre "días de serenidad", em outra ocasião, numa carta destinada ao seu amigo Jean Cassou, contradiz-se afirmando que "ese libro que parece tan ligero es el de mi más intenso drama" (UNAMUNO, 2005, p. 11). Então, em qual versão acreditar? A que remete aos dias de serenidade ou aos do mais intenso drama? Em nosso pensar, nas duas.

Recuerdos de niñez y mocedad é uma pequena obra dividida em quatro partes: Primera parte, Segunda parte, Moraleja e Estrambote. Em Primera Parte o autor fala sobre seu nascimento e infância; em Segunda parte, sobre a adolescência até o momento em que abandona Bilbao para estudar na universidade Complutense de Madrid; em Moraleja se evidenciam algumas reflexões sobre Bilbao e a infância; e em Estrambote (de estrambótico,

\footnotetext{
${ }^{4}$ Para mais informação, ler o artigo "Me duele españa!”: A crise espanhola do século xix e xx em Amor y Pedagogía de Miguel de Unamuno (2018), também da nossa autoria.

5 "El primer período comprendería desde 1884, año en que presentó su tesis doctoral, hasta 1897, cuando experimentó su profunda crisis religiosa. El segundo período, (...) se extiende desde el año indicado de 1897 hasta 1912. (...) El tercero, por fin, comprendería desde la publicación de la novela Niebla en 1913 hasta su muerte en 1936.” (FRAYLE DELGADO, 2009, p. 267).
} 
Rev. Interd. em Cult. e Soc. (RICS), São Luís, v. 6, n. 2, p. 248-264, jul./dez. 2020 ISSN eletrônico: 2447-6498

excêntrico) Miguel de Unamuno rememora algumas vivências da infância que não se enquadram tematicamente nos capítulos anteriores, findando a obra com uma curiosa exaltação à sua cidade de origem: “¡Arriba, mi Bilbao, que el porvenir es tuyo!” (UNAMUNO, 2006, p. 148).

Num olhar superficial, podemos notar que este pequeno texto memorial se apresenta como uma ode aos bons tempos da infância. Liberdade, brincadeiras típicas entre amigos em que o mais forte e o mais viril é o que sempre as ganha; cerimônias religiosas, primeiros contatos com o mundo intelectual e artístico, e algumas referências ao aspecto geográfico da vila, marcam a tônica da obra.

Entretanto, por muito que as predominâncias de vivências compartilhadas pelo autor se manifestem como brilhantes, felizes e lúdicas, tal fato não significa necessariamente que essas experiências sejam as únicas dentro do repertório existencial do escritor, nem sequer que estas experiências sejam verdadeiras. Isto ocorre porque o gênero autobiográfico que retrata a lembrança da infância, por mais que se possa pensar o contrário, não consegue ser fiel aos fatos tal e como aconteceram. Em primeiro lugar porque "el yo autobiográfico dista de ser um testigo fiel e imparcial" (BRAUNSTEIN, 2009, p. 25), e em segundo pela grande distância que há para com o eu do presente que escreve a memória, de um eu longínquo, ou seja, o eu da infância. Isso posto, os relatos de infância manifestam uma grande abrangência de lacunas que só se podem preencher mediante alterações e invenções.

Mas qual a necessidade de escrever um relato de infância? Qual a pretensão de criar uma obra marcada por biografemas (na concepção de Barthes)? Tal urgência de falar de si é uma característica nascida na modernidade - ainda que os diários, epístolas e outros textos memoriais existam desde a antiguidade. Entretanto, a partir do Iluminismo e da preocupação de assentar o eu no mundo, que o sujeito "precisa prover o eu de marcas distintivas que possam confirmar sua existência, assinalar seu pensamento e reforçar sua identidade" (OUELLETEMICHALSKA, 2007, p. 146).

A urgência moderna de apresentar-se ao mundo e apresentar-se a si mesmo, portanto, não se baseia somente na transmutação de experiências pretéritas, mas também em deixar como legado aquilo que se era. Contudo, escrever sobre si desloca ao sujeito do caminho da parcimônia, uma vez que "ela tem um papel muito próximo da confissão ao diretor espiritual [...] ela deve revelar, sem exceção, todos os movimentos da alma (omnes cogífafíones)" (FOUCAULT, 1992, p. 145). Sendo assim, adentremo-nos nos movimentos da alma de Miguel de Unamuno. 
Rev. Interd. em Cult. e Soc. (RICS), São Luís, v. 6, n. 2, p. 248-264, jul./dez. 2020

ISSN eletrônico: 2447-6498

\section{A ALMA DA INFÂNCIA DE UNAMUNO}

Unamuno publica Recuerdos de niñez y mocedad numa fase existencial, espiritual e literária caracterizada pelo grande reconhecimento da crítica. A obra, ainda que lançada ao mercado editorial em 1908 (um ano após seu romance mais aclamado e conhecido: Niebla), o processo de escrita se iniciou em 1891, quer dizer, 17 anos antes. Por que tanta demora entre o início de composição do livro e a publicação dele?

Um fato bastante esclarecedor nos é apontado pelo pesquisador Lozano Marco, o qual diz o seguinte:

El libro, en su forma definitiva, aparece en 1908, el año del fallecimiento de su madre, cuando el escritor cumple cuarenta y cuatro años y, desde esa edad madura, vuelve de nuevo los ojos a su ayer de niño, que no es sino adentrarse en su alma en busca de su centro. (LOZANO MARCO, 2001, p. 154).

As palavras do cientista espanhol justificam, em certa medida, as escolhas temáticas da obra. A morte da mãe supõe um grande choque que o faz voltar à infância para, com as ternas lembranças dos primeiros anos de existência, proteger-se da dor da perda. O próprio Unamuno “confiesa que este golpe le ha removido el peso de antiguas inquietudes, pero piensa que será por su bien, y concluye: 'es que mi madre sigue valiéndome y quiere que su muerte sea de algún fruto para mí'” (RABATÉ; RABATÉ, 2010, p. 276).

Por essa razão que, praticamente tudo quanto se narra no texto do intelectual bascuence $^{6}$, caracteriza-se pela bondade, inocência e vida santa das crianças do pueblo. Era necessário se centrar no lado positivo da infância, pois de desalento já estava cheia a vida. Não obstante, nas entrelinhas é possível destacar a aparição de algumas "manchas" no meio da pureza - entre elas a da morte do pai do autor espanhol.

Logo na primeira página da obra, fala Don Miguel da morte do progenitor: "Murió mi padre en 1870, antes de haber yo cumplido los seis años. Apenas me acuerdo de él y no sé si la imagen que de su figura conservo no se debe a sus retratos que animaban las paredes de mi casa.” (UNAMUNO, 2006, p. 9, grifo nosso). Unamuno, como visto no excerto anterior, assume que não lembra muito bem da figura paterna e tudo quanto recorda, deve-se mais aos elementos que pertencem à casa onde residia que às lembranças empíricas com Don Félix.

\footnotetext{
${ }^{6}$ Gentilício de quem nasceu na comunidade autônoma do País Basco.
} 
Rev. Interd. em Cult. e Soc. (RICS), São Luís, v. 6, n. 2, p. 248-264, jul./dez. 2020

ISSN eletrônico: 2447-6498

A memória do autor, ainda que fraca, aviva-se devido à recepção de estímulos sensitivos, os quais são importantes para recordar aquilo que por si só não se expõe à reminiscência. Coloca-o Braunstein (2009) da seguinte maneira:

La memoria se destine con el tiempo pero, a veces, también puede consolidarse, reanimarse con nuevos estímulos, recibir complementos vitamínicos y hormonales bajo la forma de fotografías, conversaciones, encuentros casuales con afónicos que se hacen elocuentes [...]. (p. 80).

Estes elementos, sendo quadros, livros e móveis, ao recordá-los Unamuno, ajudam-no a rememorar algumas experiências com o pai e características pessoais deste.

Após a morte de Don Felix, a mãe, Salomé, ${ }^{7}$ e os filhos, sentiram-se desamparados pela perda da figura do "chefe" da casa - o que produz um choque e uma ruptura na maneira de viver da família Unamuno y Jugo. Para o pequeno Miguel, a marca da morte do pai suporia a penetração de um trauma que não seria narrado, ao menos explicitamente, em mais de 100 textos autobiográficos do escritor.

Contudo, a ocorrência de que a primeira lembrança que o escritor remete na obra seja a de uma morte, e mais concretamente a do pai, é sintomático dentro do viés da psicanálise. Para Braunstein (2009, p. 192), existem dos tipos de primeira lembrança: as que aparecem nas primeiras páginas da narração e as primeiras no sentido cronológico. As recordações que aparecem nas primeiras páginas da narração têm "la llave de los armarios de la vida anímica" (p. 194).

Dessa forma, o fato de que o primeiro acontecimento escrito em Recuerdos de niñez y de mocedad apresente a morte do pai, é relevante para continuar nossa pesquisa pela tônica paternal. Sendo assim, após dizer que antes do pai falecer, nada recorda dele, Unamuno continua a narrativa expondo o seguinte:

[...] le recuerdo, sin embargo, en un momento preciso, aflorando su borrosa memoria de las nieblas de mi pasado. Era la casa un lugar casi sagrado, a donde no podíamos entrar siempre que se nos antojara; era un lugar donde había sofá, butacas y bola de espejo en que se veía uno chiquitito, cabezudo y grotesco. Un día en que mi padre conversaba en francés, con un francés, me colé yo a la sala y de no recordarle sino en aquel momento, sentado en su butaca, frente a Mr.Legorgeu, hablando con él un idioma para mí mismo misterioso, deduzco cuán honda debió de ser en mí la revelación del misterioso del lenguaje. [...] Ya desde antes de mis seis años me hería la atención del misterioso del lenguaje: vocación de filólogo! (2006, p. 9 - 10).

\footnotetext{
${ }^{7}$ Desde a morte do seu esposo, Salomé nunca usara socialmente outra roupa que a de um vestido preto, o qual simboliza o perene luto.
} 
Rev. Interd. em Cult. e Soc. (RICS), São Luís, v. 6, n. 2, p. 248-264, jul./dez. 2020 ISSN eletrônico: 2447-6498

A partir deste trecho, as memórias na obra relacionadas com o pai são todas marcadas por aspectos intelectuais. A intenção de rememorá-lo como um sujeito intelectual que instalara no filho algumas epifanias que mais tarde, quando jovem, fá-lo-iam se decidir pelo curso superior de filosofia e letras, evidenciam o falseamento amnésico que "sirven a los fines de la represión y sustitución de impresiones chocantes y desagradables” (FREUD, 1981, p. 291). Assim, a morte do pai, vivência de forte impacto na vida do pequeno Miguel de Unamuno, recobre-se da membrana do esquecimento. Ao recordar a Don Félix como um homem de apurada inteligência e ledor ávido, Unamuno está conseguindo afastar o terror, adicionando em seu lugar uma lembrança "inocente, aparentemente alejada de la angustia. Es así como se edifican los 'recuerdos encubridores' que dan refugio al corazón y descolocan la razón." (BRAUNSTEIN, 2009, p. 30).

Outra hipótese justificável para encobrir o fantasma da morte do progenitor, tem razão de ser na maneira em como Félix de Unamuno morreu. Juaristi e o casal francês Rabaté, biógrafos de renome de Miguel de Unamuno, escrevem em suas respectivas obras que o pai do autor bilbaíno morreu de tuberculose. Contudo, Laureano Robles, um dos grandes pesquisadores da obra e vida de Don Miguel, "com base em um texto de Unamuno, baseia-se na hipótese de um suicídio" (OLIVEIRA, 2016, p. 15). Mesmo que essa informação nunca tenha sido comprovada ou declarada por algum membro da família do intelectual espanhol, a lembrança encobridora adquiriria um sentido duplo, caso o suicídio fosse um fato. O primeiro sentido faria alusão à tentativa de afastamento da morte do pai da memória pessoal, e o segundo teria relação com a exclusão deste acontecimento para com o imaginário social, pois admitir que Félix se suicidou mancharia a honra de um dos sobrenomes mais conhecidos em todo o território nacional.

Independentemente da causa do falecimento do pai, é inegável que a figura paterna tem sido relevante para a formação intelectual de Miguel de Unamuno. Adicionando alguns exemplos que fundamentam nossa tese, em Recuerdos de niñez y mocedad encontramos, novamente, uma breve alusão a ele: “[...] entre los libros que formaban la librería de mi difunto padre, traídos de Méjico, donde pasó los años de su juventud [...]” (UNAMUNO, 2006, p. 45, grifo nosso); e algumas páginas depois, uma vez mais fazendo a associação entre pai - livros: “iQué efecto, Dios mío, cuando allá, en el cuarto de mi bachillerato, leí a Balmes y Donoso, únicos escritores de filosofía que encontré en la biblioteca de mi padre!” (UNAMUNO, 2006, p. 99, grifo nosso). 
Rev. Interd. em Cult. e Soc. (RICS), São Luís, v. 6, n. 2, p. 248-264, jul./dez. 2020

ISSN eletrônico: 2447-6498

Ainda que, pelo peso familiar, a morte de Don Félix seja a mais relevante para nossa análise, em Recuerdos de niñez y mocedad se narram algumas outras como a do zelador da escola $^{8}$, ou a do seu colega do ensino primário, especialmente marcante por ser a primeira que o escritor de Bilbao lembra:

Es un momento solemne cuando la muerte se nos revela por vez primera, cuando sentimos que nos hemos de morir. Recuerdo la impresión que me produjo la muerte de Jesús Castañeda, un muchacho compañero de colegio. Faltaba hacía días, sabíamos que estaba muy mal, y hablábamos de ello comentándolo. Unos decían que se moriría por haber fumado mucho, otros insinuaban el misterio de iniquidad, el prematuro vicio solitario. Y un día, sobrecogidos de temor misterioso, supimos que había muerto. (UNAMUNO, 2006, p. $51-52)$.

Entretanto, Unamuno admite que as mortes não afetam às crianças do pueblo, pois se sentem imortais:

El niño se siente inmortal; mejor dicho, está fuera de todo eso de la muerte y la inmortalidad: se siente eterno. Se siente eterno porque vive por entero en el momento que pasa. Oye hablar de la muerte, ve acaso morir, mata animales, pero no comprende la muerte, ve acaso morir, mata animales, pero no comprende la muerte. Si habla de ella es como habla de tantas otras cosas que tampoco comprende. (UNAMUNO, 2006, p. 10).

A sensação de imortalidade do pequeno Miguel se deve a um estado de ataraxia que recai na certeza de que, por muitas mortes que apareçam no círculo social do qual faz parte, nenhuma será a "minha". Por isso que a morte, a finitude daqueles que cercam a criança, produzem um sentimento ambíguo que Elias Canetti define da seguinte maneira:

El terror que un muerto yaciente produce en el ánimo de quien lo mira es sustituido por una satisfacción: el observador no es el muerto. Hubiera podido serlo. Pero quien yace es el otro. [...] Esta sensación es la que prevalece rápidamente; lo que al comienzo era terror se impregna luego de satisfacción. [...] Al margen de que nos dé vergüenza o no, es decisivo para la valoración del ser humano. Pero esto no altera para nada el hecho mismo. La situación de la sobrevivencia es la situación central del poder. (CANETTI, 2012, p. 36 $-37)$.

\footnotetext{
8 "Cuando murió Julián pensé algún tempo si nuestras infantiles intemperancias no le habrían abreviado la vida, llevándole antes de tiempo a la mansión en que le esperaban aquellos hermanos suyos." (UNAMUNO, 2006, p. 81)
} 
Rev. Interd. em Cult. e Soc. (RICS), São Luís, v. 6, n. 2, p. 248-264, jul./dez. 2020 ISSN eletrônico: 2447-6498

Dito isso, a criança não nega a morte em momento algum, mas faz dela um acontecimento a mais da vida, que, sem embargo, perpassa-lhe de longe, quase como um evento destinado àqueles que nascem com o fardo da fatalidade nas costas.

\section{4 "PAZ" EN LA GUERRA}

O século XIX na Espanha se caracteriza pelo início da decadência de uma das nações que outrora fora considerada como a mais rica e respeitada de quantas havia na Terra. A monarquia espanhola, em 1833, inicia uma contenda bélica e política que dividiu ao país em dois bandos: por um lado estavam os liberais, partidários de Isabel II - filha de Fernando VII; e no outro o irmão de Fernando VII - Carlos de Bourbón. Os dois requeriam para si o direito ao trono após o falecimento de Fernando VII e como não conseguiram chegar a um acordo, decidiram sumir ao país numa sucessão de guerras civis que chegariam ao seu fim em 1876 com a derrota do partido carlista.

Conhecidas como Guerras Carlistas, estas foram de extrema importância para a estagnação econômica e social da Espanha. Além dos fatores socioeconômicos, os espanhóis vivenciaram um profundo sentimento de terror e luto que contundiu a orgulhosa identidade ibérica. As grandes metrópoles e agrupamentos rurais foram alvo de bombardeios, contendas armadas e/ou perda de homens de todas as faixas etárias que, obrigados a se alistar ao exército de algum dos dois bandos, partiram para a guerra e nunca mais voltaram.

O pueblo de Unamuno não foi uma exceção. Don Miguel conheceu os embates da terceira Guerra Carlista em primeira pessoa ainda na tenra idade. Em Recuerdos de niñez y Mocedad, o autor significa a experiência com a guerra e posteriores consequências como o fim da infância e início da juventude (UNAMUNO, 2006, p. 69).

Aos dez anos, em 1873, a vila onde residia Unamuno e sua família, recebeu uma série de ataques aéreos que seriam narrados pelo autor da seguinte maneira:

Me acuerdo bien del día 21 de febrero, en que empezó el bombardeo. Habíanlo anunciado, pero muchos lo tomaban a broma. [...] una de las primeras bombas que llegaron a la villa, creo que la primera, cayó dos o tres casas más abajo de la nuestra. Empezó la confusión, el cierre de tiendas; vinieron a buscarnos y nos bajaron a la confitería, donde nos reunimos casi todos los vecinos de la casa. Las mujeres, lloraban algunas, los hombres trataban de animarse animándolas. (UNAMUNO, 2006, p. 69). 
Rev. Interd. em Cult. e Soc. (RICS), São Luís, v. 6, n. 2, p. 248-264, jul./dez. 2020 ISSN eletrônico: 2447-6498

Apesar desta conjuntura desoladora, o intelectual do País Basco retrata o cenário das ruínas como um novo campo onde poder brincar com seus amigos. A mutação das ruas, dos edifícios e da própria paisagem, serve como ponto de partida para "uno de los períodos más divertidos, más gratos de mi vida", e continua: "En los más recónditos senos de mi conciencia aparece el bombardeo de mi villa como edad heroico y remotísima" (UNAMUNO, 2006, p. 70).

Sendo assim, o drama da guerra se vivencia como uma etapa de novas possibilidades lúdicas, ainda que tudo ao redor estivesse se desmoronando. Um dos motivos que o autor aponta para este olhar tergiversado da criança recai na perspectiva proposital de vislumbrar a guerra como um momento de heróis, de grandes ações e de alta relevância histórica. A Guerra Carlista, pela índole política e religiosa que carregou consigo, significou para o espanhol "todo un mundo de pasiones, toda una epopeya" (UNAMUNO apud GUTIÉRREZ, 2016, p. 268).

Toda esta narrativa marcada em cima do orgulho faz sentido enquanto a vila, identificada como lugar em que nenhum acontecimento "emocionante" acontece, é atingida por uma contenda bélica que está sucedendo, simultaneamente, a nível nacional. Ora, como não se sentir importante, peça atuante no tabuleiro da grande guerra espanhola? A história estava acontecendo in situ diante dos olhos de um povo que raras vezes teve a chance ou a motivação suficiente para sair ou visitar terras além do horizonte.

O furor bélico, não obstante, acrescentou-se quando, no fim da guerra, as tropas pertencentes aos liberais entraram na vila para anunciar que o confronto havia terminado. Assim finaliza o capítulo de Recuerdos de niñez y mocedad. Ou seja, recapitulando um pouco sobre tudo o que Unamuno escreve, podemos presenciar, brevemente, a descrição da caída das bombas e as consequências destas; mas no restante do capítulo dedicado à Guerra Carlista, tudo quanto acontece é diversão, emoção, felicidade e até certa melancolia pelas sensações armazenadas daquela época.

Contudo, o narrador comenta que o fato de não explicitar mais detalhadamente os bombardeios, não se deve ao acaso, mas: "como quiera que mis recuerdos infantiles del bombardeo de mi Bilbao los he contado en mi novela Paz en la Guerra, no creo deber volver aquí sobre ello" (UNAMUNO, 2006, p. 72). Portanto, para destrinchar mais detalhadamente as lembranças infantis, devemos visitar o primeiro romance do escritor.

\subsection{Morte na Guerra}

Paz en la Guerra (1897) foi a obra ficcional, primeira e única, em que o autor falou sobre os acontecimentos pertencentes à Guerra Carlista. Outros membros da Geração do 98 se 
Rev. Interd. em Cult. e Soc. (RICS), São Luís, v. 6, n. 2, p. 248-264, jul./dez. 2020

ISSN eletrônico: 2447-6498

detiveram com mais afinco neste momento histórico - como é o caso de Ramón del ValleInclán ${ }^{9}$ (1866 -1936) -, mas Unamuno decidiu se centrar em outras temáticas - como a existencial ou a espiritual, em fim, as humanas. Esta preferência por narrar o ser em lugar do social, também é visível no romance histórico do autor. Paz en la Guerra desloca seu foco de atenção para as pequenas histórias, para as pequenas cidades e para os sujeitos periféricos que não receberam condecorações, mas que sofreram e conheceram os tormentos da guerra da mesma maneira e com a mesma intensidade que as grandes metrópoles e as grandes personalidades da contenda belígera.

Essa característica unamuniana de escrever e falar sobre os esquecidos da história, converter-se-ia, desde Paz en la Guerra, em uma constante na produção literária do autor. As intrahistórias, maneira como ele chama às narrativas do povo esquecido, surgem pela necessidade de dar voz àqueles que não aparecem nos jornais ou não são recordados nos discursos políticos:

Los periódicos nada dicen de la vida silenciosa de los millones de hombres sin historia que a todas horas del día y de la noche, en todos los países del globo, se levantan a una orden del sol y van a sus campos a proseguir la oscura y silenciosa labor cotidiana y eterna. (UNAMUNO, 2005, p. 144).

Dessa forma, Paz en la Guerra se constitui como uma homenagem aos habitantes da vila bilbaense, assim como uma obra autobiográfica associada à infância do autor. Nela, é possível vislumbrar alguns dos elementos que já descrevemos anteriormente em Recuerdos de niñez y mocedad, como as peripécias dos jovens no cenário pós-bombardeio, o orgulho patriótico por pertencer à história da nação etc. A autobiografia e o romance, portanto, diluemse numa linha tênue, quase invisível, que impossibilita saber onde começa e termina a ficção. Isto acontece porque,

Para o autor, obra é vida e vida é obra. Personagens somos todos nós, imersos na ficção vital. Portanto, a relação entre sonhador e sonhado, entre vida e ficção, borra-se em névoa. As fronteiras parecem desvanecer-se e o limite passa a ser o não limite do sonho. (CORREIA, 2013, p. 108).

O sonho, assim, faz-se vida e a vida faz-se sonho. No entrelugar do fatual e ficcional que Unamuno escreve seu romance que, sendo romance, é também vida e vice-versa. Por esta razão que podemos encontrar em Paz en la Guerra elementos autobiográficos do autor, como

\footnotetext{
${ }^{9}$ Caso o leitor sinta curiosidade, recomendamos a tese da Dra. Raquel da Silva Ortega: Carlismo de Valle-Inclán: a modernidade antimoderna em La Guerra Carlista (UFRJ)
} 
Rev. Interd. em Cult. e Soc. (RICS), São Luís, v. 6, n. 2, p. 248-264, jul./dez. 2020

ISSN eletrônico: 2447-6498

o olhar orgulhoso ${ }^{10}$ dos bilbaenses que já descrevemos em páginas anteriores. Contudo, o que encontramos de inédito na obra de 1897 são as mortes e outros eventos dramáticos que em Recuerdos de niñez y mocedad são velados.

O romance descreve as vidas das pessoas de um pueblo ao norte da Espanha - cujo nome não é desvelado em momento algum - que tentam viver apesar do caos que paira sobre o país e sobre a própria vila. Na obra, não só se fala "sobre la última guerra carlista y el sitio de Bilbao que él mismo presenciara en su niñez", mas também, “sobre lo que fue y entrañó el movimiento carlista para el pueblo vasco, sobre sus causas y antecedentes y, muy en particular, sobre aquella aparente identificación de pueblo vasco y carlismo" (GUTIÉRREZ, 1986, p. 268 - 269). Por isso que o leitor identifica eventos históricos da Guerra Carlista, assim como o sentimento do luto - elementos que só podíamos intuir em Recuerdos de niñez y mocedad.

A morte, lembrança encobrida na infância do intelectual, aparece em Paz en la guerra com recorrência, sendo o falecimento de Ignácio, personagem principal da obra, a mais significativa dentre todas:

"Cuando supo Pachico por una carta la muerte de Ignacio dióle um vuelco el
corazón. Se dijo: "¡Pobrecillo!" y fuese a casa, en la que se encerró para dejar
correr libres sus lágrimas allí, donde nadie le viera llorar. Entonces descubrió
cuánto le había querido y, espoleando al llanto, para hallar en éste un recogido
deleite de abandono y de fusión de afectos, perdióse en imaginaciones vagas.
¿¿Una vida perdida? ¿Perdida... para quién? ¿Para él acaso, para el pobre
Ignacio?”. (UNAMUNO, 1999, p. 1986).

Após a morte do protagonista, o narrador relata a imensa dor sentida pelos habitantes do pueblo, dado que Ignácio era um jovem querido por todos eles.

Descrito o argumento central do romance, cabe-nos formular a seguinte pergunta: por que somente na ficção que Unamuno fala da morte de maneira explícita? Por que na autobiografia ele a esconde? Ora, ainda que o eu autobiográfico pretenda ser fiel e imparcial no relato de si, a memória impossibilita que esta missão seja efetuada com eficiência, principalmente quando esta se encontra cicatrizada por lembranças traumáticas. Por isso que Freud (1981) menciona que "se recuerda para mejor olvidar o desconocer” (p. 301).

\footnotetext{
${ }^{10}$ Um trecho de Paz en la Guerra em que se faz apologia à guerra, é o seguinte: "Formábanse una fresca y poética visión de la guerra, una visión enteramente homérica, zurciendo con detalles de lo que veían sueños y retazos de cosas entreoídas y vislumbradas. ¡Qué gustazo oír contar aquellas cosazas y tener que contarlas! ¡Qué gustazo bordar mentiras sobre la verdad y poetizar la guerra! Oíanse con la boca abierta; mientras los mayores sufrían la guerra, sacábanle ellos la poesía. Viviendo al día, con voluntad virgen, descuidados del mañana y desinteresados de las pasiones que agitaban la lucha, ciegos a las con secuencias, las causas y el fondo de ellas, veían sólo su forma pura, un juego preñado de inusitadas emociones" (UNAMUNO, 1999, p. 202).
} 
Rev. Interd. em Cult. e Soc. (RICS), São Luís, v. 6, n. 2, p. 248-264, jul./dez. 2020 ISSN eletrônico: $2447-6498$

Na autobiografia, o eu se posiciona perto do texto. Não há apenas distância entre aquele que escreve e aquele que é narrado, mesmo que esse micro distanciamento seja suficiente para que o autor morra nas mãos da palavra, fazendo-o sombra da "substância líquida" (DERRIDA, 2005, p.14) que representa a obra. Dito de outra forma, aquele que escreve sobre si o faz com a pretensão de anunciar a verdade, não obstante, ao se situar no patamar do fatual, já está ingressando na "zona de atração desse ponto donde o verdadeiro é excluído" (BLANCHOT, 2011, p. 51).

Já a ficção possibilita um distanciamento mais amplo entre o autor e o texto, dado que, no romance, o verdadeiro, como absoluto e como intenção, não é concebível. Embora que a efeitos práticos, a ficção seja um componente inerente à autobiografia, na intencionalidade é que vemos as diferenciações entre o narrador autobiográfico e o ficcional. Aquele que produz um texto ficcional o faz com o propósito de transitar pela fantasia das palavras; ao mesmo tempo em que, aquele que escreve, posicionando-se obliquamente na autobiografia, sempre sentirá de perto o olhar vigiador do outro.

Assim, o romance Paz en la guerra cede ao escritor a possibilidade de narrar mais abertamente aquilo que foi reprimido quando criança, isto é, a morte de entes queridos, a destruição das ruas e edifícios da vila, e os lamentos dos habitantes do povo bilbaíno. Por outro lado, Recuerdos de niñez y mocedad serve como ponte para que o eu adulto possa voltar à infância, escrevê-la, valer-se dela "sob pretexto de suprir a memória” (DERRIDA, 2005, p.47).

\section{CONSIDERAÇÕES FINAIS: A ESCRITA COMO PHÁRMAKON}

Como temos visto anteriormente, Recuerdos de niñez y mocedad é uma obra narrada com a intenção de retornar às águas tranquilas da infância. A morte de Salomé, mãe de Unamuno, criou no autor o estímulo último para a escrita da única obra que, em sua totalidade, fala dos primeiros anos da vida. A temática da obra, ainda que permeada de recordações luminosas, positivas e lúdicas, deixa entrever um quê de ficção que, segundo Freud, serve para encobrir certas lembranças traumáticas de felicidade.

A morte de Don Félix, pai de Unamuno, da mãe, de amigos da infância, assim como os bombardeios por parte dos bandos enfrentados na Guerra Carlista, marcam a infância de uma criança que, quando adulta, transmuta essas vivências por meio do olhar inocente e santo, para que, ao voltar às fontes da existência, possa atualizar as lembranças e, a partir delas, vivificálas esplendorosamente na memória. 
Rev. Interd. em Cult. e Soc. (RICS), São Luís, v. 6, n. 2, p. 248-264, jul./dez. 2020

ISSN eletrônico: 2447-6498

Entretanto, o processo da escrita não se fundamenta somente no benéfico, mas aflora no escritor um sentimento paradoxal, uma ambiguidade que Derrida chama de phármakon:

Não há remédio inofensivo. O phármakon não pode jamais ser simplesmente benéfico. (...) A essência ou a virtude benéfica de um phármakon não o impede de ser doloroso. (...) Esta dolorosa fruição, ligada tanto à doença quanto ao apaziguamento, é um phármakon em si. Ela participa ao mesmo tempo do bem e do mal, do agradável e do desagradável. Ou, antes, é no seu elemento que se desenham essas oposições. (DERRIDA, 2005, p. 56-7).

Dessa forma, o remédio, o phármakon, a escrita, assume o papel de curar ao escritor, pois a partir desse processo que o autor vai mitigando o pesar da existência. Contudo, também o faz recordar aquilo que justamente tenta desviar e/ou manipular. Para alterar a lembrança escondida nos recônditos da alma, é preciso, antes de tudo, fazê-la presente, expô-la sobre si, mirá-la cara a cara para, a partir daí, torná-la objeto:

No mundo, as coisas são transformadas em objetos a fim de serem apreendidas, utilizadas, tornadas mais seguras, na firmeza distinta de seus limites e na afirmação de um espaço homogêneo e divisível - mas, no espaço imaginário, transformadas no inapreensível, fora de uso e de usura, não a nossa possessão, mas o movimento da despossessão, que nos despoja delas e de nós próprios, onde nem elas nem nós estamos já abrigados, mas somos introduzidos sem reserva num lugar onde nada nos retém. (BLANCHOT, 2011, p. 151-152)

Portanto, só quando a lembrança pertence ao autor é que pode exercer algum tipo de influência sobre ela - eis o poder da escrita.

Por essa razão que Unamuno prefere ver a história como criação e não como um amontoado de fatos que acontecem de maneira ininterrupta rumo ao progresso. Sem a narração íntima das pessoas e sem as intrahistórias que determinam o verdadeiro caráter e anseios do povo espanhol, não é possível falar de uma verdadeira e genuína história que importa, ou seja, a história do povo:

La historia no es el pasado solo, no es la tradición, no es tampoco el porvenir, el progreso. La historia es el presente eterno. Y es el crecimiento íntimo, de dentro a fuera, el enriquecimiento del contenido espiritual. En la historia vive el pasado con el porvenir y engendrándolo en un presente eterno. Porque la historia es el espíritu y el espíritu es la creación. (UNAMUNO, 1980, p. 63, grifo nosso)

O autor se permite, em Recuerdos de niñez y mocedad, lembrar para esquecer e esquecer para lembrar uma infância que, mesmo sendo formada de um emaranhado de fios - como diria 
Rev. Interd. em Cult. e Soc. (RICS), São Luís, v. 6, n. 2, p. 248-264, jul./dez. 2020

ISSN eletrônico: 2447-6498

Doubrovksy ${ }^{11}-$, impossíveis de destravar e decifrar, são essenciais para curar a um sujeito marcado pela morte, pela vida e pelo trauma. Unamuno, portanto, defende a modificação voluntária da memória para a inauguração de um eu mais puro, ou seja, um eu pretérito que, afastado dos embates da existência, significa o mundo, tornando-o mais vivo, mais feliz, mais criança.

\author{
Vuelvo a ti, mi niñez, como volvía \\ a tierra a recobrar fuerzas, Anteo, \\ cuando en tus brazos yazgo en mí, me veo; \\ es mi asilo mejor tu compañía. \\ De mi vida en la senda eres el guía \\ que me aparta del torpe devaneo; \\ purificas en mí todo deseo, \\ eres el manantial de mi alegría. \\ (UNAMUNO, 1958, p. 90).
}

\title{
REFERÊNCIAS
}

BLANCHOT, Maurice. O espaço literário. Rio de Janeiro: Rocco, 2011.

BRAUNSTEIN, Néstor A. Memoria y espanto O el recuerdo de infancia. México: SIGLO XXI, 2009.

CANETTI, Elias. La conciencia de las palabras. Barcelona: Galaxia Gutenberg, 2012.

CORREIA, Cristiane Agnes Stolet. O universo autobiográfico do bufão trágico Don

Miguel de Unamuno. Tese (Doutorado em Ciência da Literatura) - Faculdade de Letras da Universidade Federal do Rio de Janeiro, Rio de Janeiro, p. 175, 2013.

DERRIDA, Jacques. A farmácia de Platão. São Paulo: Iluminuras, 2005.

DOUBROVKSY, Serge. Le livre brisé. Paris: Grasset \& Fasquelle, 1989.

FOUCAULT, Michel. A escrita de si. In: O que é um autor? Lisboa: Passagens. 1992.

FRAYLE DELGADO, Luis. Una dialéctica del eros en Amor y Pedagogía. Azafea: Revista de Filosofía, Salamanca, v. 3, p. 265-283, 2009.

FREUD, Sigmund. Sobre los recuerdos encobridores. In: Obras completas. Buenos Aires, Amorrortu, 1981.

\footnotetext{
11 “O relato de infância é uma impossibilidade; existe uma fabulação em torno de algumas lembranças esparsas e vagas, um emaranhado de fios que se desmancham quando se escava o passado. O relato de infância é totalmente fabricado, já que a infância se encontra fora da narrativa porque está fora do tempo. Ao tentar recaptura-la, ela não se desenrola, ela se enrola." (DOUBROVKSY, 1989, p. 339).
} 
Rev. Interd. em Cult. e Soc. (RICS), São Luís, v. 6, n. 2, p. 248-264, jul./dez. 2020

ISSN eletrônico: 2447-6498

GUTIÉRREZ, Jesús. Unamuno entre la épica y la intrahistoria: Relectura de Paz en la Guerra. Actas del IX Congreso de la Asociación Internacional de Hispanistas, 1986, p. 265 - 274.

Disponível em: http://www.cervantesvirtual.com/obra/unamuno-entre-la-epica-y-laintrahistoria-relectura-de-paz-en-la-guerra-/. Acesso em: 15 de abril de 2019.

JUTGLAR, A. Ideologías y clases en la España contemporánea (1874-1931). Ed. Cuadernos para el Diálogo, S.A.: Madrid. 1973.

LINS, R. L. O conceito de morte na Era da atrocidade. In: A violência na literatura. Tempo Brasileiro, n. 58, 1980, p.7-19.

LOZANO MARCO, Miguel Ángel. Recuerdos de niñez y de mocedad. Unamuno y el alma de la niñez. Anales de literatura española, v.14, 2001. p. 151 - 164. Disponível em:

http://www.cervantesvirtual.com/obra/recuerdos-de-ninez-y-de-mocedad-unamuno-y-el-almade-la-ninez/ Acesso em: 13 de março de 2019.

OLIVEIRA, Vanessa Aparecida. Niebla: do humor à carnavalização literária. Dissertação (Mestrado em Estudos de Literatura) - Faculdade de Letras da Universidade Federal de São Carlos, São Paulo, p. 98, 2016.

OUELETTE-MICHALSKA, Madeleine. Autofiction et dévoliement de soi. Montréal: XYZ, 2007.

RABATÉ, Colette; RABATÉ, Jean-Claude. Miguel de Unamuno: Biografía. $3^{\text {a }}$ ed. Taurus: Madrid, 2010.

UNAMUNO, Miguel de. Andanzas y visiones españolas. In: Obras Completas, I. Madrid: Biblioteca Castro, 1958.

UNAMUNO, Miguel de. Cartas del destierro: entre el odio y el amor. In: Obras Completas, VIII. Madrid: Biblioteca Castro, 1958.

UNAMUNO, Miguel de. De mi país. In: Obras completas, I. Madrid: Biblioteca Castro, 1958.

UNAMUNO, Miguel de. En torno al casticismo. Madrid: Ediciones Cátedra, 2005.

UNAMUNO, Miguel de. Ensayos y artículos. Buenos Aires: Centro de Editor de América Latina, 1980.

UNAMUNO, Miguel de. Paz en la guerra. Madrid: Ediciones Cátedra, 1999.

UNAMUNO, Miguel de. Recuerdos de niñez y mocedad. Madrid: Alianza Editorial, 2006.

WOOLF, Virginia. Momentos de vida. Um mergulho no passado e na emoção. Rio de Janeiro: Nova Fronteira, 1986. 